\title{
Phytohormones Influence on the In-Vitro Regeneration of Saccharum Officinarum L. from Apical Meristem Culture
}

\author{
F. E. Lawyer (Corresponding author) \\ Biotechnology Unit, National Centre for Genetic Resources and Biotechnology \\ PMB 5382 Moor plantation, Ibadan, Oyo state, Nigeria \\ Tel: 234-806-251-7996 E-mail: ja2708@yahoo.com
}

Z. O. Jamaleddine

Tel: 234-805-856-7113 E-mail: glizzy00@yahoo.com

P. T. Lyam

Tel: 234-806-350-2051ｅmail: pauliam003@ gmail.com

I. T. Borokini

Tel: 2348063502051 E-mail: tbisrael@gmail.com

\section{A. A. Adedeji}

Tel: 234-805-764-6689 E-mail: kbspecial4real@yahoo.com
A. U. Okere

Tel: 234-803-604-2204 E-mail: oaugoton@yahoo.com

Received: January 10, 2014 Accepted: January 27, 2014

doi:10.5296/jbls.v5i2.4885 URL: http://dx.doi.org/10.5296/jbls.v5i2.4885 


\section{Abstract}

Growth regulators especially auxins and cytokinins are critical for plant in-vitro regeneration. The effect of these plant growth regulators on in-vitro propagation of Saccharum officinarum $\mathrm{L}$ (Sugarcane) was investigated. In vitro response of two different varieties of sugarcane (NCS 005 and NCS 008) to Plant Growth Regulators was obtained in this study. Formation of buds was obtained on shoot apical meristem when cultured on MS (Murashige and Skoog) medium supplemented with $0.1 \mathrm{mg} / \mathrm{l}$ BAP (6-Benzylaminopurine). After two weeks of initiation, regenerated meristem was inoculated into MS (Murashige and Skoog) fortified with different concentrations and combination of cytokinins. Shoot multiplication was optimal on $0.5 \mathrm{mg} / \mathrm{l}$ $\mathrm{BAP}+0.25 \mathrm{mg} / \mathrm{l} \mathrm{Kin(Kinetin)}$ for NCS 005 variety while for NCS 008 variety, no significant $(\mathrm{P} \geq 0.05)$ difference was observed between $1.5 \mathrm{mg} / \mathrm{l} \mathrm{BAP}$ and $1.5 \mathrm{mg} / 1 \mathrm{BAP}+0.5 \mathrm{mg} / \mathrm{l} \mathrm{Kin}$. The best root induction for in vitro derived shoots was obtained on $1.0 \mathrm{mg} / \mathrm{l} \mathrm{NAA}$ (Naphthalene acetic acid) and $2.0 \mathrm{mg} / \mathrm{lBA}$ ( Indole butyric acid) for both varieties of sugarcane within ten days of culture transfer. Successfully established plantlets showed excellent growth response when weaned under regulated green house conditions.

Keywords: Plant growth regulators, Murashige and Skoog, 6-Benzylaminopurine, Naphthalene acetic acid, Indole butyric acid, Kinetin

\section{Introduction}

Saccharum officinarum L (Sugarcane) a perennial herb belonging to the Poaceae family.It is one of the most important sugar crops in the world which accounts for about $70 \%$ of the world's total sugar production (Anonymous, 2005). This distinguishing quality place a high value on the species as a commercial crop especially in Nigeria where it has been highly cultivated. Saccharum officinarum is a polyploid plant that is grown in different parts of the world. Sugarcane importance has increased over time and in recent years becoming an important industrial raw material for sugar industries and other industries producing alcohol, and animal feed. Saccharin officinarum is mainly propagated vegetative by two to three budded sets. This traditional practice results in high production cost and also a large amount of sugarcane involvement in the cultivation process. Considering the importance in the agricultural industry, concerted efforts are being made for its improvement (Desai et al 2004). Tissue culture technique is an alternative method to overcoming these challenges and to produce uniform propagules for the cultivation, (Nickell, 1964, Heinz and Mee 1969). Micro propagation is important for rapid multiplication of elite genotypes/clones and for the quick spread of new varieties (Nickell and Heinz, 1973). Micro propagation is established, not only as means of clonal and rapid propagation it is also more efficient in a viable and successful method for the production of pathogen free planting materials. In recent decades, in vitro shoot tip culture for mass propagation of sugarcane has been reported by (Hendre et al, 1983; Lee, 1987; Nand and Singh,1994.). In vitro regeneration through leaf sheath culture and plant regeneration through callus culture (Nickell, 1977) has also been reported. The in vitro nutrition requirements for Saccharum officinarum vary according to genotypes as well as explants used. In vitro cultivation method has proven to be an efficient regeneration method for mass propagation of this crop and production of uniform and disease free propagules for 
potential and quality production of sugarcane. In order to ensure highest possible yield and quality of field crops, the disease free stock can be extended to the growers and out growers by using this technique (Aamir et al 2008). Present research focuses on the importance of tissue culture technology in Saccharum officinarum improvement and establishment of efficient micro propagation protocols for healthy, disease free and premium quality planting materials in Nigeria.

\section{Material and Methods}

Two varieties, NCS005 and NCS008 were obtained from National Cereal Research Institute (NCRI), Badeggi, Nigeria. The varieties were established on the field gene bank of the National Centre for Genetic Resources and Biotechnology (NACGRAB), Ibadan. Apical sections, containing 6-8cm long spindle segment with growth tips and young leaf shealths were collected from the two varieties within 2-4 months old. These collected plants materials were taken into the NACGRAB Biotech lab, where they were washed under running tap water with addition of few drops of household liquid detergents for 20-30 minutes. The apical portions were immersed in $70 \%$ Ethanol for 5 min followed by disinfection with $50 \%$ v/v (volume per volume) commercial bleach for $20 \mathrm{mins}$. These were further rinsed several times with sterile distilled water. Meristems were kept in $0.001 \% \mathrm{w} / \mathrm{v}$ (weight per volume) citric acid solution for 30 minutes before excision. All surface sterilization was done under sterile conditions. Using the left and right leaf shealths remover technique, the surface sterilized spindle segments were aseptically dissected out into $2 \mathrm{~cm}$ long meristems with the help of sterile surgical blades and forceps. The apical meristems were immediately inoculated in MS medium (Murashige and Skoog, 1962) containing 3\%(w/v) sucrose, B5 vitamins, 0.01g/L ascorbic acid and 0.7\%(w/v) agar. MS basal media was supplemented with different concentrations and combinations of Plant Growth Regulators. The $\mathrm{pH}$ of the medium was adjusted to 5.8 and autoclaved at $121^{\circ} \mathrm{C}$ and $15 \mathrm{lb}$ for $15 \mathrm{~min}$ (Desai et al 2004). Cultures were maintained in the growth room at an incubation temperature of $23^{\circ} \mathrm{C} \pm 1^{\circ} \mathrm{C}$ with 8 to 16 hour photoperiod.

For axillary shoot proliferation, budding meristems were transferred to MS containing increased cytokinin concentrations. Shoot formation and proliferation was observed after 7 - 20 days of shoot initiation. First sub-culturing was done after three weeks and subsequent sub-culturing after every fourth night. All dead shoots were removed at each sub-culture.

For in-vitro rooting, MS medium containing different concentrations and combination of NAA and IBA was used. Successfully rooted in-vitro sugarcane plantlets were acclimatized in a humid environment, prior to transfer to outside conditions. During acclimatization, plantlets were protected from high temperature and irradiance.

All data were subjected to analysis of variance (ANOVA) using SAS software package and the means were separated using Duncan Multiple Range Test at 5\% level of significance (Gbadamosi et al 2013).

\section{Results}

\subsection{Shoot Formation from Apical Meristem}


Enlargement, swelling and browning of the sugarcane explants were observed after 8 day of culture in all the media combinations. After $10-15$ days of culture auxiliary shoot proliferation occurred from the base of explants, these differ from each media due to the varieties.

\subsubsection{Multiplication of Shoot}

Generally, best results for shoot multiplication were obtained in semi solid medium. The effect of plant growth regulators (PGRs) revealed differences in growth responses for both varieties (see Tables 1 and 2). During secondary proliferation stage, lateral shoots were formed at the base of newly initiated shoots in both varieties. As a result, a dense mass of shoots (15-20) was developed in each culture bottle. Shoot multiplication was maintained by regular transfer to new medium. This was achieved by sub-dividing shoots in clusters containing 4-5 shoots and transferring them into fresh MS medium augmented with different concentrations and combinations of cytokinins. For NCS 005, BAP in combination with KIN provided better results for shoot formation as compared to the use of BAP alone. Among different concentrations used, $0.5 \mathrm{mg} / \mathrm{l}$ of BAP with $0.25 \mathrm{mg} / \mathrm{l}$ Kinetin conferred the best shoot formation response (Table 1). For NCS 008, the best results for shoot formation (4.0 \pm 0.0 ) was observed on BAP at concentration $1.5 \mathrm{mg} / \mathrm{L}$, with this being in proximity with shoot formation (3.6 \pm 0.33 )observed on $2.0 \mathrm{mg} / \mathrm{L}$ BAP. However, for NCS 008 , there was no significant difference $(\mathrm{P} \geq 0.05)$ observed between results obtained on $\mathrm{MS}+1.5 \mathrm{mg} / \mathrm{L}$ and $\mathrm{MS}+1.5 \mathrm{mg} / \mathrm{L}$ $\mathrm{BAP}+0.5 \mathrm{mg} / \mathrm{L}$ Kin (Table 1$)$.

\subsubsection{Rooting of Regenerated Shoots}

Root initiation in the successfully established shoots was achieved on MS medium supplemented with different auxin concentrations. The effect of different plant growth regulators on root length in Saccharum officinarum was significant $(\mathrm{P} \leq 0.05)$ (Table2). The best root induction for in vitro derived shoots was obtained on $1.0 \mathrm{mg} / \mathrm{l}$ NAA and $2.0 \mathrm{mg} / \mathrm{lBA}$ for both varieties of sugarcane within ten days of culture transfer. An average shoot number of $6.0 \pm 0.57$ and $10.0 \pm 1.67$ were produced for NCS 005 and NCS008 respectively (see Table 2). The lowest mean value of $2.00 \pm 0.00 \mathrm{~cm}$ was obtained in MS media that had $1.00 \mathrm{mg} / \mathrm{l} \mathrm{NAA}$ and $0.50 \mathrm{mg} / \mathrm{l} \mathrm{IBA}$ in case of NCS 005 while for NCS $008 \mathrm{MS}$ media that had $0.50 \mathrm{mg} / \mathrm{l} \mathrm{NAA}$ (Table 2).

Table1. Effect of different plant growth regulators and their concentration on establishment of shoot Variety, NCS 005

\begin{tabular}{|c|c|c|c|c|}
\hline Media & Concentration mg/l & $\begin{array}{c}\text { Number } \\
\text { of explants }\end{array}$ & Shoot number/explants & Shoot length(cm) \\
\hline MS+BAP & 0.5 & 20 & $1.00 \pm 0.00^{\mathrm{e}}$ & $1.32 \pm 0.01^{\mathrm{d}}$ \\
\hline MS+BAP & 1.0 & 20 & $1.33 \pm 0.33^{\text {de }}$ & $1.27 \pm 0.10^{\mathbf{d}}$ \\
\hline MS+BAP & 1.5 & 20 & $1.67 \pm 0.33^{\text {de }}$ & $1.72 \pm 0.05^{\text {d }}$ \\
\hline MS+BAP & 2.0 & 20 & $2.00 \pm 0.00^{\text {cd }}$ & $1.81 \pm 0.10^{\text {d }}$ \\
\hline MS+BAP & 2.5 & 20 & $2.00 \pm 0.00^{\text {cd }}$ & $1.56 \pm 0.23^{\text {d }}$ \\
\hline MS+BAP+KIN & $0.5+0.25$ & 20 & $5.00 \pm 0.00^{\mathbf{a}}$ & $4.56 \pm 0.37^{\mathbf{c}}$ \\
\hline
\end{tabular}




\begin{tabular}{|c|l|l|l|l|}
\hline MS+BAP+KIN & $1.0+0.25$ & 20 & $3.00 \pm 0.00^{\mathbf{b}}$ & $5.20 \pm 0.15^{\mathbf{c}}$ \\
\hline MS+BAP+KIN & $1.5+0.50$ & 20 & $2.66 \pm 0.33^{\mathbf{b}}$ & $6.09 \pm 0.21^{\mathbf{b}}$ \\
\hline MS+BAP+KIN & $2.0+0.50$ & 20 & $2.66 \pm 0.66^{\mathbf{b c}}$ & $6.66 \pm 0.33^{\mathbf{b}}$ \\
\hline MS+BAP+KIN & $2.5+0.50$ & 20 & $2.43 \pm 0.21^{\mathbf{b c}}$ & $7.70 \pm 0.60^{\mathbf{a}}$ \\
\hline
\end{tabular}

Variety, NCS 008.

\begin{tabular}{|c|c|c|c|c|}
\hline Media & Concentration mg/l & $\begin{array}{c}\text { Number of } \\
\text { explants }\end{array}$ & Shoot no/explants & Shoot length (cm) \\
\hline MS+BAP & 0.5 & 20 & $2.00 \pm 0.00^{\mathrm{c}}$ & $3.25 \pm 0.00^{\mathrm{ab}}$ \\
\hline MS+BAP & 1.0 & 20 & $2.33 \pm 0.33^{\mathrm{c}}$ & $3.90 \pm 0.00^{\mathrm{ab}}$ \\
\hline MS+BAP & 1.5 & 20 & $4.00 \pm 0.00^{\mathrm{a}}$ & $4.60 \pm 0.06^{\mathrm{a}}$ \\
\hline MS+BAP & 2.0 & 20 & $3.60 \pm 0.33^{\mathrm{a}}$ & $2.25 \pm 0.00^{\mathrm{b}}$ \\
\hline MS+BAP & 2.5 & 20 & $2.66 \pm 0.33^{\mathrm{bc}}$ & $4.50 \pm 1.25^{\mathrm{a}}$ \\
\hline MS+BAP+KIN & $0.5+0.25$ & 20 & $2.00 \pm 0.00^{\mathrm{c}}$ & $3.60 \pm 0.35^{\mathrm{ab}}$ \\
\hline MS+BAP+KIN & $1.0+0.25$ & 20 & $2.33 \pm 0.33^{\mathrm{c}}$ & $4.00 \pm 0.45^{\mathrm{ab}}$ \\
\hline MS+BAP+KIN & $1.5+0.50$ & 20 & $4.00 \pm 0.00^{\mathrm{a}}$ & $4.70 \pm 0.05^{\mathrm{a}}$ \\
\hline MS+BAP+KIN & $2.0+0.50$ & 20 & $3.33 \pm 0.33^{\mathrm{ab}}$ & $3.80 \pm 0.11^{\mathrm{ab}}$ \\
\hline MS+BAP+KIN & $2.5+0.50$ & 20 & $2.30 \pm 0.33^{\mathrm{c}}$ & $4.50 \pm 1.23^{\mathrm{a}}$ \\
\hline
\end{tabular}

Values (mean \pm standard deviation) in a column followed by same letter are not significantly different $(\mathrm{P} \geq$ $0.05)$

Table2. Effect of different auxin and their concentrations on root initiation variety NCS 005 .

\begin{tabular}{|c|c|c|c|c|}
\hline Media & Concentration mg/l & $\begin{array}{c}\text { Number of } \\
\text { explants }\end{array}$ & Root number/explants & Root length (cm) \\
\hline MS+NAA & 0.5 & 20 & $2.33 \pm 0.33^{\mathbf{d e}}$ & $1.10 \pm 0.01^{\text {def }}$ \\
\hline MS+NAA & 1.0 & 20 & $2.00 \pm 000^{\mathbf{e}}$ & $1.76 \pm 0.56^{\text {cd }}$ \\
\hline MS+NAA & 1.5 & 20 & $3.00 \pm 0.00^{\mathbf{d}}$ & $0.70 \pm 0.00^{\mathbf{f}}$ \\
\hline MS+NAA & 2.0 & 20 & $2.66 \pm 0.33^{\mathbf{d e}}$ & $1.23 \pm 0.07^{\text {def }}$ \\
\hline MS+IBA & 0.5 & 20 & $2.00 \pm 0.00^{\mathbf{e}}$ & $0.80 \pm 0.00^{\mathbf{f}}$ \\
\hline MS+IBA & 1.0 & 20 & $2.00 \pm 0.00^{\mathbf{e}}$ & $0.90 \pm 0.20^{\mathbf{e f}}$ \\
\hline MS+IBA & 1.5 & 20 & $3.00 \pm 0.00^{\mathbf{d}}$ & $1.10 \pm 0.00^{\text {def }}$ \\
\hline MS+IBA & 2.0 & 20 & $2.33 \pm 0.33^{\mathbf{d e}}$ & $1.60 \pm 0.40^{\mathbf{c d e}}$ \\
\hline MS+NAA+IBA & $1.0+1.0$ & 20 & $4.00 \pm 0.00^{\mathbf{c}}$ & $2.10 \pm 0.00^{\mathbf{b c}}$ \\
\hline MS+NAA+IBA & $1.0+2.0$ & 20 & $6.00 \pm 0.57^{\mathbf{a}}$ & $3.50 \pm 0.23^{\mathbf{a}}$ \\
\hline MS+NAA+IBA & $2.0+1.0$ & 20 & $5.00 \pm 0.00^{\mathbf{b}}$ & $3.90 \pm 0.00^{\mathbf{a}}$ \\
\hline MS+NAA+IBA & $2.0+2.0$ & 20 & $5.00 \pm 0.00^{\mathbf{b}}$ & $2.60 \pm 0.10^{\mathbf{b}}$ \\
\hline
\end{tabular}

Variety NCS 008

\begin{tabular}{|c|c|c|c|c|}
\hline Media & Concentration mg/l & $\begin{array}{c}\text { Number } \\
\text { of explants }\end{array}$ & Root number/explants & Root length (cm) \\
\hline MS+NAA & 0.5 & 20 & $2.33 \pm 0.33^{\mathrm{d}}$ & $0.70 \pm 0.00^{\mathrm{f}}$ \\
\hline MS+NAA & 1.0 & 20 & $2.33 \pm 0.33^{\mathrm{d}}$ & $2.30 \pm 0.23^{\text {cd }}$ \\
\hline
\end{tabular}




\begin{tabular}{|c|c|c|c|c|}
\hline MS+NAA & 1.5 & 20 & $3.00 \pm 0.00^{\text {cd }}$ & $2.30 \pm 0.00^{\text {cd }}$ \\
\hline MS+NAA & 2.0 & 20 & $4.30 \pm 0.66^{\text {bcd }}$ & $0.80 \pm 0.00^{\mathrm{f}}$ \\
\hline MS+IBA & 0.5 & 20 & $4.00 \pm 0.00^{\text {bcd }}$ & $0.80 \pm 0.00^{\mathrm{f}}$ \\
\hline MS+IBA & 1.0 & 20 & $5.00 \pm 0.00^{\mathrm{bc}}$ & $2.00 \pm 0.00^{\mathrm{d}}$ \\
\hline MS+IBA & 1.5 & 20 & $5.00 \pm 0.00^{\mathrm{bc}}$ & $2.40 \pm 0.00^{\mathrm{cd}}$ \\
\hline MS+IBA & 2.0 & 20 & $4.00 \pm 1.00^{\mathrm{bcd}}$ & $2.26 \pm 0.23^{\mathrm{d}}$ \\
\hline MS+NAA+IBA & $1.0+1.0$ & 20 & $6.00 \pm 0.00^{\mathrm{b}}$ & $2.90 \pm 0.00^{\mathrm{b}}$ \\
\hline MS+NAA+IBA & $1.0+2.0$ & 20 & $10.00 \pm 1.67^{\mathrm{a}}$ & $3.50 \pm 0.30^{\mathrm{a}}$ \\
\hline MS+NAA+IBA & $2.0+1.0$ & 20 & $5.00 \pm 0.00 \mathrm{~b}^{\mathrm{c}}$ & $1.50 \pm 0.00^{\mathrm{e}}$ \\
\hline MS+NAA+IBA & $2.0+2.0$ & 20 & $5.66 \pm 0.66^{\mathrm{b}}$ & $2.73 \pm 0.17^{\mathrm{bc}}$ \\
\hline
\end{tabular}

Values (mean \pm standard deviation) in a column followed by same letter are not significantly different $(\mathrm{P} \geq 0.05)$

Figures 1. Photograph showing the tissue cultured explants at different steps of the micropropagation
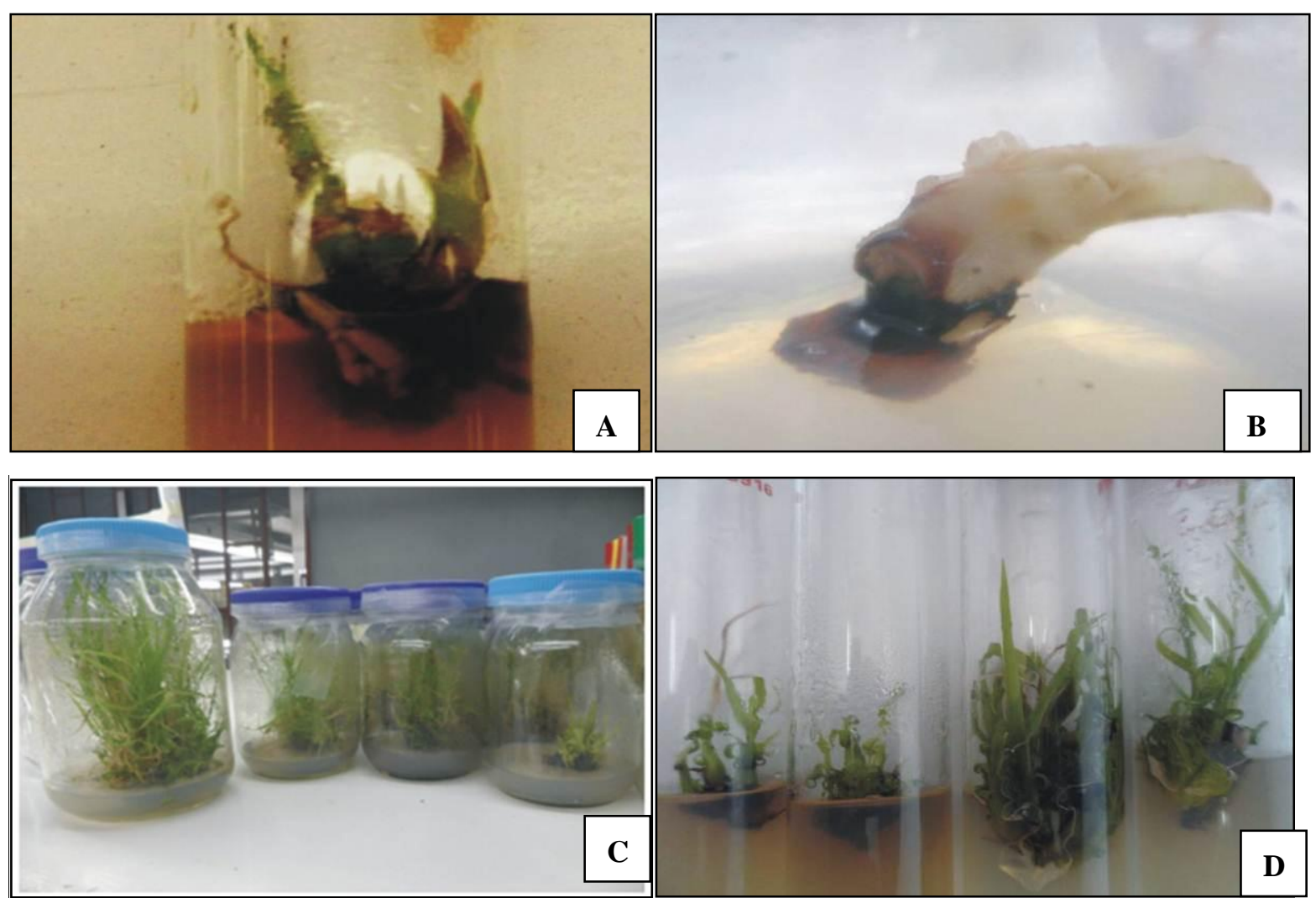


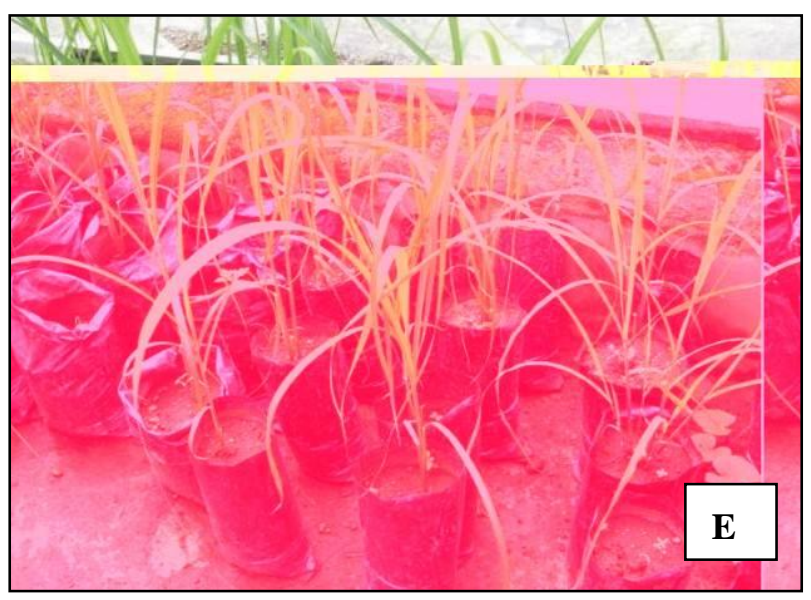

Key of Photograph showing the tissue cultured explants at different steps of the micropropagation
A. Apical meristem cultured in regeneration medium
B. Shoot induction of variety NCS 008 with auxiliary shoot after 10 days
C. Sub cultured sugarcane variety NCS 005 shoots after 2 weeks
D. Sugarcane in culture bottles
E. Sugarcane in the screen house.

\subsubsection{Hardening and Acclimatization of Plants of in Vitro Raised Plants}

The in-vitro plants were hardened and acclimatized in medium containing a mixture of in River Sand, Topsoil, coconut fibers (1:2:2) after three weeks of transplanting in screen house. After 21 days the potted plant were nurtured in poly pots placed under sunlight for further hardening of the plantlets. These seedlings were transfer to the field after another two weeks and a high rate of seedlings were transferred successfully. Hardening was carried out in screen house under natural light conditions.

\section{Discussion and Conclusion}

In graminaceous species, plant regeneration has been facilitated by the identification of appropriate explant and in vitro culture conditions (Vasil, 1987, Gbadamosi et al 2013). The method of producing large number of identical clones by in-vitro culture is being routinely used for wide range of plant species (Biondi, 1986, Aamir Ali et al 2008). In this study, different concentration and combination of auxin and cytokinins in MS Medium was successfully utilized for shoot organogenesis and multiple shoot regeneration from apical meristems of sugarcane. This concurs with report by Yutaka et al 1998, that combination of phytohormones often determines the course of morphogenesis (shoot organogenesis or embryogenesis). This study also reconfirms the new phase for plant multiplication for the production of efficient, genetically stable clonal germplasm and pathogen free stock (Hussey, (1983); and Kartha (1986). The best shoot formation and proliferation for both varieties was observed on BAP in combination with KIN. Many authors including Shukla, 1994; Geeta, 
2001; Dhillon, et al 2002 and Aamil Ali et al 2008 have reported the use of kinetin in combination with BAP for shoot formation in sugarcane

When auxins were used singly, an average of two to three roots was observed in NCS005. Conversely, NCS008 showed a more roubust root formation on MS fortified with IBA only, as compared to MS fortified with NAA. This indicates that IBA is a more preferred auxin regarding effeiciency and yield for invitro root initiation in the NCS008 variety.

A combination of NAA and IBA was however observed to yield the best results for root formation in both varieties. (Anbalagan et al., 2000 and Nadgauda 2002) had earlier reported that a combination of two auxins (NAA and IBA) promotes rooting in sugarcane, also favoured the combination of NAA and IBA promote for rooting. Also the combination of IBA and NAA best for rooting, and this favoured both when he combined NAA and IBA.

Several authors including Yi et al,(2004), Pruski et al.,(2005) and Aamil Ali et al.,(2008) has also reported optimum results in the combination of NAA and IBA for rooting in Phragmites communis and two different varieties of sugarcane.

Following Sreenivasan and Sreenivasan (1992) which observed 90-95\% survival of plantlets in poly screen house under shade, the simple method of hardening, adopted in this study facilitated the successful transfer of $90 \%$ of Saccharum officinarum plants from in vitro to ex vitro conditions.

This study indicates and strongly support the statement by (Aamil Ali et al 2008) that micro propagation is not only feasible but it can be used as the helpful tool for rapid multiplication of disease free, high yielding and premium quality planting material of highly adapted, genetically stable and newly released varieties of sugarcane.

\section{Acknowledgments}

The authors wish to acknowledge the National Centre for Genetic Resources and Biotechnology (NACGRAB), NCRI, Badeggi, Nigeria, for the support during the research work, Mr. Ibor Denis of NACGRAB for his effort in raising the sugarcane plantlet in the screen house and the establishment on the field and also to all that supported the research work.

\section{Reference}

Aamir A, Shagufta N., Fayyaz A. S., \& Javed I. (2008). An efficient protocol for large scale production of sugarcane through micropropagation. Pak. J. Bot., 40(1), 139-149.

Anbalagan, S., A. Kalamani \& M. Sakila. (2000). In vitro propagation of sugarcane: nature of callus, direct regeneration, regeneration through callus and morphological variations. Res. On Crops, 1(2), 138-140.

Anonymous, (2005), Crop husbandary for sugarcane mericlones. Sugarcane Breeding

Biondi, (1986) Practical application of in vitro propagation: Present situation and future prospects. Giom. Bot. Ital., 120, 29-42.

Desai N. S., Suprasanna P., \& Bapat V. A. (2004). Simple and reproducible protocol for direct 
somatic embryogenesis from cultured immature inflorescence segments of sugarcane (Saccharum spp.).Current science, vol. 87(6), 764-768.

Dhillon, B. D. S., G Raman \& S. S. Gosal. (2002). Evaluation of different plant delivery system in micro propagated sugarcane (saccharum officinarum L.). Crop impro. 29(1), 35 - 40

Gbadamosi A. E., \& Shaibu B. (2013). Influence of the phytohormones on the in-vitro regeneration in Senna alata (Linn). Academia Journal of Biotechnology, 1(3), 041-045.

Geeta, S., \& D. Padmanabhan. (2001). Effect of hormones on direct somatic embryogenesis in sugarcane. Sugar Tech., 3(3), 120-121. http://dx.doi.org/10.1007/BF03014576

Heinz, D. J., \& Mee, G. W. P., (1969), Plant differentiation from callus tissue of Saccharum $\begin{array}{llll}\text { species, } & \text { Crop } & \text { Sci. } & \text { 346-348. }\end{array}$ http://dx.doi.org/10.2135/cropsci1969.0011183X000900030030x

Hendre, R. R., Iyer, R. S., \& Kotwal, M., (1983), Rapid multiplication of sugarcane by tissue culture. Sugarcane, 1,58 .

Hussey, G (1983). Plant Biotechnology. Cambridge University Press. Cambridge, 111-138.

Institute Report (Quarterly), 12, 2.

Jyoti R. Rout \& William J. Lucas 1996 Characterization and manipulation of embryogenic response from in-vitro-cultured immature inflorescences of rice (Oryza sativa L.) Springer-Verlag, 198(1), 127-138

Kartha, K. K. (1986). Elimination of viruses in the presence of Antivirus chemicals production and indeang of disease free plants. 219-238.

Lee, T. S. G. (1986). Multiplication of sugarcane by apex culture. Tumalba, 36, 231-235.

Lee, T. S. G., (1987). Micro propagation of sugarcane (Saccharum sp.) Plant Cell Tissue and Organ culture, 10, 47-55. http://dx.doi.org/10.1007/BF00037496

Murashige, T., \& Skoog, F., (1962), A revised medium for rapid growth and bioassays with $\begin{array}{lllll}\text { tobacco tissue } \quad \text { culture. } & \text { Physiol. } & \text { Plant, } & \text { 15, }\end{array}$ http://dx.doi.org/10.1111/j.1399-3054.1962.tb08052.x

Nadgauda, R. S. (2002.). Need for tissue culture. Tissue culture pilot plant, National Chemical Laboratory, Pure 1-4.

Nand, L, \& H. N. Singi., (1994). Rapid colonal multiplication of sugarcane through tissue culture plant .Tissue culture, 4, 1-7.

Nickell, L. G. (1977). Crop improvement in sugarcane: studies using in vitro methods. Crop Science. 17, 717-719. http://dx.doi.org/10.2135/cropsci1977.0011183X001700050011x

Nickell, L. G., \& Heinz, D. J., (1973). Potential of cell and tissue culture techniques as aidsin economic plant improvement. In: Genes enzymes and populations. Plenum, N.Y., A. M. SRB Publications, 109-128. 
Nickell, L.G., (1964). Tissue and Cell Culture of sugar-cane: Another research tool. Hawaii Planters Records. 57, 223-229.

Pruski, K., T. Astatkie, \& J. Nowak. (2005). Tissue culture propagation of Mngolian cherry (Prunus fruticosa) and Nanking cherry (Prunus tomentosa) Plant Cell Tissues and Organ Culture., 82(2), 207-211. http://dx.doi.org/10.1007/s11240-004-7836-6

Shukla, R. A. Q. Khan \& G. K. Gang. (1994). In vitro clonal multiplication of sugarcane; Optimization of media and hardening of plants. India. 89-94.

Sreenivasan, T. V., \& Sreenivasan, J. (1992), Micro propagation of sugarcane varieties for Increasing cane yield. Sugar Tech Journal., 18, 61-64.

Vasil, I. K. (1987), Developing cell and tissue culture systems for the improvement of cereals and grass crops. Journal of Plant Physiology. 1987, 128, 192-218. http://dx.doi.org/10.1016/S0176-1617(87)80234-1

Yi, M., Yi. Guo, Yang, Z. Guo \& G. Chen. (2004). Adventitious shoot bud formation and plant regeneration from in vitro-cultured stem segments of reed (Phragmites communis Trin.). In vitro cellular and developmental Biology, 40(4), 412-415. http://dx.doi.org/10.1079/IVP2004553

Yutaka,T. Y, Tomohiro, M. Toshikazu \& O. Takeshi. (1998). Plant regeneration via shoot organogenesis from cotyledons in two wild Cucumis species, C. figarei and C. metuliferus Japan Agricultural Research Quarterly., 32, 281-286.

\section{Copyright Disclaimer}

Copyright for this article is retained by the author(s), with first publication rights granted to the journal.

This is an open-access article distributed under the terms and conditions of the Creative Commons Attribution license (http://creativecommons.org/licenses/by/3.0/). 